\title{
Brain weights in adult africans ${ }^{a}$
}

\section{SALAMI, A. ${ }^{1 *}$, AJANI, M. ${ }^{2}$, ORHORHO, I. ${ }^{3}$, OGUN, G. ${ }^{1}$, ADEOYE, A. ${ }^{1}$, OKOLO, C. ${ }^{1}$, OLUWASOLA, A. ${ }^{1}$ and OGUNBIYI, J. ${ }^{1}$}

\author{
${ }^{1}$ Department of Pathology, University of Ibadan, 200212, Ibadan, Oyo state, Nigeria \\ ${ }^{2}$ Department of Pathology, Babcock University, 121103, Ilishan-Remo, Ogun state, Nigeria \\ ${ }^{3}$ Department of Neurological Sciences, University of Ibadan, 200212, Oyo state, Nigeria \\ *E-mail: ayodejisalami@gmail.com
}

\begin{abstract}
Introduction: The average brain weight of adult humans, using Caucasian figures, is said to be between $1300 \mathrm{~g}$ to $1400 \mathrm{~g}$. Few studies have however been done to make actual evaluations of brain weights in adult Africans. This study seeks to examine the weight of brains from people of African descent with respect to variations in sex and age in decades using autopsy specimens. Materials and Methods: Analysis of the weight of brains removed from both male and female adult patients during fresh autopsy of their bodies in our center over a ten year period was done. The study criteria required non-involvement of the central nervous system in the cause of death. The brains were grouped based on age in decades and further grouped into early, middle and late age groups. Descriptive statistical analysis was done using SPSS 20 statistics software. Results: A total of one hundred and sixteen brains were included in the study and the mean brain weight was $1280 \mathrm{~g}$ with a range between $1015 \mathrm{~g}$ to $1590 \mathrm{~g}$. There was no statistically significant difference in the mean brain weight of the different age groups. The average male brain was heavier than those of females and the difference was statistically significant. Conclusion: The brain weight of adult Africans in our study is similar to that seen in Caucasians. There is no statistically significant difference in the brain weight of adults from early adulthood to the elderly adults. Male adults have statistically heavier brains than the females.
\end{abstract}

Keywords: brain, weights, African, gender, autopsy.

\section{Introduction}

The human brain constitutes approximately two percent of the body weight and controls most of the activities of the body both consciously and subconsciously. The average brain weight of adult humans is said to be between $1300 \mathrm{~g}$ to $1400 \mathrm{~g}$ from data derived from Caucasian populations (RUSHTON and ANKNEY 1996; HARTMANN, RAMSEIER, GUDAT et al., 1994). Studies done by several authors has found the brain of Caucasians to weigh more than that of blacks and have generated a lot of controversy (RUSHTON and ANKNEY 2009). There is however a paucity of studies done to determine the average brain weight in Africans. The importance of such studies is further enhanced by the linking of intelligence quotients of individuals to the weight of the brains which has been found to differ in different sexes and different age groups (RUSHTON and ANKNEY 1996).

The brain is one of the organs which also show variation in weight between sexes. Studies have shown that the average brain weight in males is more than that of females in Caucasian populations (RUSHTON and ANKNEY 2009). Odokuma et al had earlier shown a reduction in the calculated weight of brains from males compared to females in three black populations (ODOKUMA, GERALD and VHITERHIRE 2010). The weight of the brain also shows some variation in different populations of the same race according to some studies (RUSHTON and ANKNEY 2009; ODOKUMA, GERALD

a The abstract of this article submission was presented at the University of Ibadan 2016 Conference of Biomedical research. and VHITERHIRE 2010; JAHANSHAHI, GOLALIPOUR, and HEIDARI 2008). A finding which has been attributed to historical migration patterns and intermarriages (ODOKUMA, IGBIGBI, AKPUAKA et al., 2010).

Few studies have been done to make actual evaluations of brain weights in adult Africans. This study seeks to determine the actual weight of brains from people of African descent with respect to variations in sex and age in decades using autopsy specimens.

The study also seeks to examine the mean brain weight of a black population of subjects in the background of previously published studies of brain weights in Caucasian populations.

\section{Materials and Methods}

Analysis of the weight of brains removed from both male and female adult patients during fresh autopsy of their bodies in our hospital facility over a ten year period was done. The criteria for the study requires that the brain should be from patients twenty years of age and above, should have no gross morphologic defects such as moderate to severe oedema, intracranial haemorrhage, space occupying lesions, exudate of any type, features of neurodegeneration or developmental anomalies and the disease process responsible for the death of the patient should not have shown involvement of central nervous system clinically and radiologically.

The brains were removed following standard autopsy procedure with the brain stem severed from the spinal cord at the level of the foramen magnum. The dura mater was 
completely removed and the weight of the whole brain was determined with the cerebrum, brainstem and cerebellum attached and intact. All the brains were weighed using the same weighing balance with standard counterweights.

The overall mean brain weight and the mean brain weights of the two separate gender were derived from the obtained data. The patients ages were categorized into groups which comprised the third to the eight decades. The third and fourth decades (representing early adulthood), fifth and sixth decades (representing middle age) and the seventh and eight decades were further combined together to form three separate groups each made up of weights of brains of individuals spanning two decades. These combinations allowed comparison of brain weights in early adulthood, middle age and elderly age groups. Statistical analysis of the data was done using SPSS 20 statistics software to determine the descriptive statistics and independent sample t test was used to determine the relationship between the two gender while ANOVA was used to compare the means of the different age groups. A significance level of 0.05 was used in the analysis.

\section{Results}

A total of 3500 autopsies were done in the hospital facility during the ten year period. One hundred and sixteen brains met the study criteria and were included in the study. Sixty four of the brains came from male adults while 52 were from females. The youngest of the patients whose brain was weighed was 21 years of age while the oldest was 75 years. The mean brain weight was $1280 \mathrm{~g}$ with a range between $1015 \mathrm{~g}$ to $1590 \mathrm{~g}$.

The mean weight of male brains was $1334 \mathrm{~g}$ with a difference of $480 \mathrm{~g}$ between the heaviest and the lightest brain. The mean female brain weight was 1213 and showed a difference of $485 \mathrm{~g}$ between the extremes of brain weight (Table 1). There was a $10.93 \%$ reduction in the mean brain weight of females compared to that of males. The ratio of male to female brain weight is 1.1:1 and there was a significant statistical difference between the two groups $(\mathrm{p}<.001)$.

The mean brain weight of the early adult age group differed by only one gram with the mean brain weight in middle age group (Figure 1). There was a reduction in the mean brain weight of the elderly age group with the first two groups by seven and six

Table 1. Brain weight in Male and Female brains.

\begin{tabular}{lccc}
\hline & Mean & Minimum & Maximum \\
\hline $\begin{array}{l}\text { Weight of } \\
\text { male brains }\end{array}$ & 1333.75 & 1100 & 1590 \\
$\begin{array}{l}\text { Weight of } \\
\text { female brains }\end{array}$ & 1212.50 & 1015 & 1500 \\
\hline
\end{tabular}

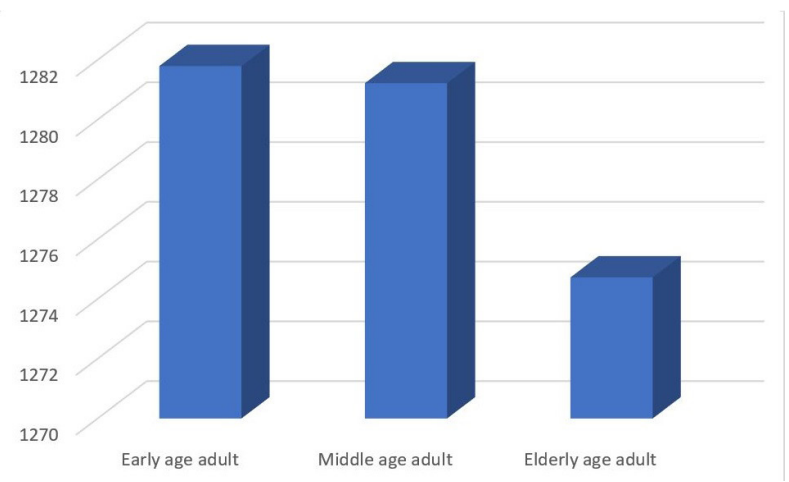

Figure 1. Mean brain weight in adult ages. grams respectively. There was however no statistical difference between the early adult group brain weights with the middle age group $(\mathrm{p}=.168)$ and the elderly adult groups $(\mathrm{p}=.690)$.

\section{Discussion}

The mean brain weight in this study was $1280 \mathrm{~g}$ which is lower than the mean weight obtained by Odokuma et al in their study using craniometry (ODOKUMA, GERALD and VHITERHIRE 2010). This difference may actually be due to the limitation of the method they used which may not reflect the variations with age in the rigid skull. Their study was thus limited to individuals in the third to fourth decades of life since there was no further growth of the skull beyond this age. The mean brain weight in this study is however higher than the findings by Rushton et al (RUSHTON and ANKNEY 2009). Several studies have shown differences in mean brain weights derived from the same population, a feature which has been attributed to the different methods used in deriving the data (RUSHTON and ANKNEY 2009; JAHANSHAHI, GOLALIPOUR and HEIDARI, 2008). Some studies have also shown that there are variations in brain weight with regard to body size, a factor which has not been proven (HARTMANN, RAMSEIER, GUDAT et al., 1994; RUSHTON and ANKNEY 2009).

Our study showed a difference in the mean brain weight of males and females. This finding is consistent with previous other studies done which has shown a higher brain weight in males compared to females (HARTMANN, RAMSEIER, GUDAT et al., 1994; ODOKUMA, GERALD and VHITERHIRE 2010; DEKABAN, 1978; ZAIDI, 2010; SKULLERUD, 1985). The differences in brain weights between the sexes have been attributed by some authors to differences in body size while other authors have suggested other factors which may account for the differences (ZAIDI, 2010). Despite larger sizes and volumes in men, the female brain has been found to have larger cortical thickness and several larger subcortical grey matter areas (LUDERS, GASER, NARR et al., 2009). The superior temporal gyrus in the Wernicke's area is particularly noted to significantly have more thickness in the female (LUDERS, GASER, NARR et al., 2009). Rabinowicz et al has however shown a different result from their studies which showed no differences in cortical thickness in males and females. Rather their study showed males to have thirteen percent increase in the number of neurons compared to females and it is believed to account for the differences in weight (RABINOWICZ, DEAN, PETETOT et al., 1999). Their findings however suggested that there are more synapses in the female cortex. This finding was corroborated by Gong et al. who showed that the female brain was more efficient than the male due to increase in neural connectivity (GONG, ROSA-NETO, CARBONELL et al., 2009). According to their study, though the female brain has less neurons, they are more closely packed and have shorter intercellular signal transmission time (LÜDERS, STEINMETZ and JÄNCKE 2002).

The male to female brain weight ratio seen in our study is similar to what previous studies has shown (SKULLERUD, 1985; RABINOWICZ, DEAN, PETETOT et al., 1999). The $10.9 \%$ difference between the male and female brains is similar to the values obtained by Debakan and Hartmann et al who got $9.8 \%$ and $9.0 \%$ respectively (HARTMANN, RAMSEIER, GUDAT et al., 1994; DEKABAN, 1978). These findings suggest that the apparent difference in male and female brain weights is not functional as the increase in 
the number of neurons in the male brain is made up by the increase in the volume of fibers in the female (RABINOWICZ, DEAN, PETETOT et al., 1999; LÜDERS, STEINMETZ and JÄNCKE 2002). Several studies have shown that the height of the individual also serves as a determinant in the weight of their brain which might also account for the differences in the sexes since men are often taller (HARTMANN, RAMSEIER, GUDAT et al., 1994; DEKABAN 1978; SKULLERUD, 1985).

Mean brain weight in the early adult (third and fourth decade of life) did not differ with the mean weight in the middle age adult (fifth and sixth decade of life) in this study. Although the mean weight in the elderly adults (seventh and eight decades) showed an apparent decrease with the previous two groups statistical comparison showed no true difference between the groups. Many studies have shown decrease in brain weights with age and begins from about the age of twenty years (RUSHTON and ANKNEY 1996; HARTMANN, RAMSEIER, GUDAT et al., 1994; RUSHTON and ANKNEY 2009; TERRY, DETERESA and HANSEN 1987). Hartmann et al found a relative decrease of about $2.5 \mathrm{~g}$ per year in both sexes but other studies showed an increase in the loss of brain substance by about $5 \mathrm{~g}$ per year by the age of eighty (HARTMANN, RAMSEIER, GUDAT et al., 1994; RUSHTON and ANKNEY 2009). Some authors have shown that the decrease in the mean brain weight becomes evident starting from the sixth decade (TERRY, DETERESA and HANSEN 1987; GIORGIO, SANTELI, TOMASSINI et al., 2010).

The decrease in brain weight with age has been attributed to reduction in the number of neurons due to ongoing cell loss which is most prominent in the frontal and temporal regions of the brain (CURIATI, TAMASHIRO, SQUARZONI et al., 2009). Recent studies have however shown that the decrease in the brain weights of elderly individuals is not totally due to loss of neuronal cells but more attributable to a reduction in the size of large pyramidal cells (GONG, ROSA-NETO, CARBONELL et al., 2009; GIORGIO, SANTELI, TOMASSINI et al., 2010; CURIATI, TAMASHIRO, SQUARZONI et al., 2009). The reduction in the size of pyramidal cells is made up by a concomitant increase in the number of small neurons which is most seen in the frontal and temporal regions of the brain (GONG, ROSANETO, CARBONELL et al., 2009; CURIATI, TAMASHIRO, SQUARZONI et al., 2009). Furthermore, the aged brain has shown a significant reduction in the volume of white matter which is due to a reduction in the number of synaptic connections (GONG, ROSA-NETO, CARBONELL et al., 2009).

\section{Conclusion}

Our study shows that the mean brain weight in a black African population is higher than previously thought. The mean brain weight of males is higher than that of females in this study population as seen in the Caucasian population with similarity in the ratio. There is no reduction in mean brain weight with age in this study population as against the previously described studies in the Caucasian population. There is however a need for a future larger study which will be more representative of the population.

\section{References}

CURIATI, PK., TAMASHIRO, JH., SQUARZONI, P., DURAN, FL., SANTOS, LC., WAJNGARTEN, M., LEITE, CC., VALLADA, H., MENEZES, PR., SCAZUFCA, M., BUSATTO, GF. and ALVES, TC. Brain structural variability due to aging and gender in cognitively healthy elders: results from the São Paulo ageing and health study. American Journal of Neuroradiology, 2009, vol. 30, n. 10, p. 18501856. PMid:19661175. http://dx.doi.org/10.3174/ajnr.A1727.

DEKABAN, AS. Changes in brain weights during the span of human life: relation of brain weights to body heights and body weights. Annals of Neurology, 1978, vol. 4, n. 4, p. 345-356. PMid:727739. http://dx.doi.org/10.1002/ana.410040410.

GIORGIO, A., SANTELI, L., TOMASSINI, V., BOSNELL, R., SMITH, S., DE STEFANO, N. and JOHANSEN-BERG, H. Age-related changes in grey and white matter structure throughout adulthood. NeuroImage. 2010, vol. 51, n. 3, p. 943-951. http:// dx.doi.org/10.1016/j.neuroimage.2010.03.004.

GONG, G., ROSA-NETO, P., CARBONELL, F., CHEN, ZJ., HE, $\mathrm{Y}$. and EVANS, AC. Age- and gender-related differences in the cortical anatomical network. The Journal of Neuroscience, 2009, vol. 29, n. 50, p. 15684-15693. PMid:20016083. http://dx.doi.org/10.1523/ JNEUROSCI.2308-09.2009.

HARTMANN, P., RAMSEIER, A., GUDAT, F., MIHATSCH, MJ. and POLASEK, W. Normal weight of the brain in adults in relation to age, sex, body height and weight. Der Pathologe, 1994, vol. 15, n. 3, p. 165-170. PMid:8072950. http://dx.doi.org/10.1007/ s002920050040.

JAHANSHAHI, M., GOLALIPOUR, MJ. and HEIDARI, K. The effect of ethnicity on facial anthropometry in Northern Iran. Singapore Medical Journal, 2008, vol. 49, n. 11, p. 940-943. PMid:19037564.

LUDERS, E., GASER, C., NARR, KL. and TOGA, AW. Why sex matters: brain size independent differences in gray matter distributions between men and women. The Journal of Neuroscience, 2009, vol. 29, n. 45,p. 14265-14270. PMid:19906974. http://dx.doi.org/10.1523/ JNEUROSCI.2261-09.2009.

LÜDERS, E., STEINMETZ, H. and JÄNCKE, L. Brain size and grey matter volume in the healthy human brain. Neuroreport, 2002, vol. 13, n. 17, p. 2371-2374. PMid:12488829. http://dx.doi. org/10.1097/00001756-200212030-00040.

ODOKUMA, IE., GERALD, F. and VHITERHIRE, C. Pattern of brain weight in three West African populations. TAF Preventive Medicine Bullletin, 2010, vol. 9, n. 4, p. 321-324

RABINOWICZ, T., DEAN, DE., PETETOT, JM. and DE COURTENMYERS, GM. Gender differences in the human cerebral cortex: more neurons in males; more processes in females. Journal of Child Neurology, 1999, vol. 14, n. 2, p. 98-107. PMid:10073431. http:// dx.doi.org/10.1177/088307389901400207.

RUSHTON, JP. and ANKNEY, CD. Brain size and cognitive ability: correlations with age, sex, social class, and race. Psychonomic Bulletin and Review, 1996, vol. 3, n. 1, p. 21-36.

RUSHTON, JP. and ANKNEY, CD. Whole brain size and general mental ability: a review. The International Journal of Neuroscience, 2009, vol. 119, n. 5, p. 691-731. http://dx.doi.org/10.1080/00207450802325843. PMid:19283594.

SKULLERUD, K. Variations in the size of the human brain. Influence of age, sex, body length, body mass index, alcoholism, alzheimer changes, and cerebral atherosclerosis. Acta Neurologica Scandinavica. Supplementum, 1985, vol. 102, p. 1-94. PMid:3887832.

TERRY, RD., DETERESA, R. and HANSEN, LA. Neocortical cell counts in normal human adult aging. Annals of Neurology, 1987, vol. 21, n. 6, p. 530-539. PMid:3606042. http://dx.doi.org/10.1002/ ana.410210603.

ZAIDI, ZF. Gender differences in human brain: a review. The Open Anatomy Journal, 2010, vol. 2, p. 37-55. http://dx.doi.org/10.21 74/1877609401002010037. 